\title{
The contribution of groundwater discharge to the overall water budget of two typical Boreal lakes in Alberta/Canada estimated from a radon mass balance
}

\author{
A. Schmidt ${ }^{1}$, J. J. Gibson ${ }^{2}$, I. R. Santos ${ }^{3}$, M. Schubert ${ }^{1}$, K. Tattrie ${ }^{2}$, and H. Weiss ${ }^{1}$ \\ ${ }^{1}$ Helmholtz-Centre for Environmental Research - UFZ, Permoserstrasse 15, 04318 Leipzig, Germany \\ ${ }^{2}$ Alberta Research Council, Victoria, British Columbia, Canada \\ ${ }^{3}$ Centre for Coastal Biogeochemistry, Southern Cross University, Lismore, NSW, Australia
}

Received: 10 July 2009 - Published in Hydrol. Earth Syst. Sci. Discuss.: 21 July 2009

Revised: 27 November 2009 - Accepted: 16 December 2009 - Published: 14 January 2010

\begin{abstract}
Radon-222, a naturally-occurring radioisotope with a half-life of 3.8 days, was used to estimate groundwater discharge to small lakes in wetland-dominated basins in the vicinity of Fort McMurray, Canada. This region is under significant water development pressure including both oil sands mining and in situ extraction. Field investigations were carried out in March and July 2008 to measure radon-222 distributions in the water column of two lakes as a tracer of groundwater discharge. Radon concentrations in these lakes ranged from 0.5 to $72 \mathrm{~Bq} / \mathrm{m}^{3}$, while radon concentrations in groundwaters ranged between 2000 and $8000 \mathrm{~Bq} / \mathrm{m}^{3}$. A radon mass balance, used in comparison with stable isotope mass balance, suggested that the two lakes under investigation had quite different proportions of annual groundwater inflow (from $0.5 \%$ to about $14 \%$ of the total annual water inflow). Lower discharge rates were attributed to a larger drainage area/lake area ratio which promotes greater surface connectivity. Interannual variability in groundwater proportions is expected despite an implied seasonal constancy in groundwater discharge rates. Our results demonstrate that a combination of stable isotope and radon mass balance approaches provides information on flowpath partitioning that is useful for evaluating surface-groundwater connectivity and acid sensitivity of individual water bodies of interest in the Alberta Oil Sands Region.
\end{abstract}

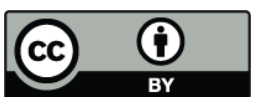

Correspondence to: A. Schmidt (axel.schmidt@ufz.de)

\section{Introduction}

Northeastern Alberta is the centre of oil sand mining in Canada. The intense mining activities in the vicinity of the City of Fort McMurray were established some decades ago. The processes of oil extraction, upgrading and refinement require significant inputs of water, some of which is withdrawn from local aquifers.For in situ mining purposes, groundwater is pumped from the available aquifer system to the surface where it is heated up and re-injected as steam into the oil bearing sands. The resultant decrease in the viscosity of the bitumen allows its pumping to the surface. This practice may trigger considerable changes in the local groundwater flow patterns. One concern related to this process is the potential ecological effect on hydraulically connected surface water bodies.

Water exchange between surface waters and connected aquifer systems generally provide major pathways for the transfer of dissolved matter (Burnett et al., 2006; Santos et al., 2008a). Even in areas where no anthropogenic groundwater contamination is present, an alteration in the groundwater/surface water exchange rate may have a significant qualitative and quantitative impact on natural processes, such as the transfer of dissolved carbon, oxygen, and/or nutrients. Such variations in material transfer rates across the surface water/groundwater interface can be major drivers of changes in biogeochemical processes in the affected surface water bodies, thereby potentially triggering alterations in established (eco-)systems. Assessing groundwater discharge into the surface water body is an important part of predicting the future status of a surface water ecosystem.

The oil sand region surrounding Fort McMurray is rich in lakes and ponds. They vary in size from a few hundred square metres to several square kilometres. Several studies evaluating the effect of ongoing mining and processing

Published by Copernicus Publications on behalf of the European Geosciences Union. 
activities on the aquatic ecosystems in the region have been undertaken in the last two decades (Henriksen et al., 1992; Gibson et al., 2002). For instance, the influence of $\mathrm{NO}_{\mathrm{x}}$ and $\mathrm{SO}_{\mathrm{x}}$ emissions from oil refinery operations was studied at 449 lakes and ponds within the region (Western Resource Solutions, 2004). In another study individual water budgets were calculated for numerous lakes applying an isotope-based approach including physical and climatological data sets (Bennett et al., 2008). While overall water yield rates were calculated, no distinction was made between surface runoff and groundwater inflow, preventing a quantitative estimation of the influence of the local mining activities on near surface hydrological processes.

The objective of the study discussed here is to present a qualitative and quantitative estimation of the significance of groundwater input to the overall water budget of two typical lakes in the oil sand region of northeastern Alberta, Canada. The two lakes were chosen from a larger number of investigated lakes for two reasons: they differ substantially in size and sediment composition, and they were part of the survey carried out by Bennett et al. (2008) which suggested they had contrasting flushing rates, residence times, and inflows.

\section{Material and methods}

\subsection{Theoretical background}

Radon-222 ( ${ }^{222} \mathrm{Rn}$, in the following referred to as "radon") is a radioactive noble gas that is produced by radioactive decay of radium-226. Both are members of the natural uranium238 decay chain. Radium-226 occurs in rocks, soils, and sediments within a wide range of concentrations. Hence, it can be found in virtually every aquifer matrix. Radon, which emanates from the aquifer material where it is produced, enters the groundwater and is transported with it. In the water phase, radon decays or re-equilibrates with the surrounding radium-226 to a different concentration.

In contrast to groundwater, lake waters lack major contact to radon emanating mineral. They also usually contain very low concentrations of dissolved radium-226. Hence, the concentration of radon found in lake waters is several orders of magnitude lower than in groundwater. As a result, groundwater discharge gives rise to significantly elevated radon concentrations in lake water. Once discharged into a lake, radon starts to decrease as a result of radioactive decay and atmospheric evasion. Due to its half-life of 3.8 days, radon is a useful tracer for the investigation of processes occurring within a time scale of up to 15 days.

The approach of using radon as a natural geochemical tracer for studying groundwater discharge into lakes is thoroughly described by Schmidt and Schubert (2007). Hence, the theoretical background is given here only in brief.
The assessment of groundwater discharge rates using radon as tracer is based on: (i) the quantitative identification of all radon sources and sinks in the system studied; (ii) the measurement of the excess radon inventory (i.e. the radon inventory that is not supported by the decay of ${ }^{226} \mathrm{Ra}$ dissolved in the water) in a water column representative of the lake water body (under the consideration of homogeneous groundwater discharge through the lake bottom and a well mixed lake water body); (iii) the determination of the total (diffusive and advective) radon input flux into the lake needed to balance that excess radon inventory; and (iv) the calculation of the advective component of the total radon input flux, which can be converted into a groundwater flux by using the radon concentration of the discharging groundwater as the end member.

The radon sources in a lake are the advective and diffusive radon fluxes from the sediment into the water column ( $F_{\text {adv }}$ and $F_{\text {diff }}$, respectively; $\left[\mathrm{Bq} / \mathrm{m}^{2} / \mathrm{d}\right]$ ) and the decay of ${ }^{226} \mathrm{Ra}$ dissolved in the water $\left(\lambda_{\mathrm{Rn}} I_{\mathrm{Ra}} ;\left[\mathrm{Bq} / \mathrm{m}^{2} / \mathrm{d}\right]\right)$ where $\lambda_{\mathrm{Rn}}$ is the decay constant of radon $\left[\mathrm{d}^{-1}\right]$ and $I_{\mathrm{Ra}}$ is the ${ }^{226} \mathrm{Ra}$ inventory (radium concentration $\times$ water depth; $\left[\mathrm{Bq} / \mathrm{m}^{2}\right]$ ). It is assumed that ${ }^{226} \mathrm{Ra}$ and radon are in secular decay equilibrium. The radon sinks include radon degassing to the atmosphere $\left(F_{\text {atm }} ;\left[\mathrm{Bq} / \mathrm{m}^{2} / \mathrm{d}\right]\right)$ and decay $\left(\lambda_{\mathrm{Rn}} I_{\mathrm{Rn}} ;\left[\mathrm{Bq} / \mathrm{m}^{2} / \mathrm{d}\right]\right)$ where $I_{\mathrm{Rn}}$ is the radon inventory in the water column. At steady state conditions $\left(\Sigma_{\text {sources }}=\Sigma_{\text {sinks }}\right)$ the following radon mass balance can be set up for a surface water body:

$F_{\text {adv }}+F_{\text {diff }}+\lambda_{\mathrm{Rn}} I_{\mathrm{Ra}}=\lambda_{\mathrm{Rn}} I_{\mathrm{Rn}}+F_{\mathrm{atm}}$

Radon degassing across the air-water interface generally causes significant radon losses from surface water bodies. Its rate depends on the intensity of turbulent gas transfer and on the concentration gradient at the water/air interface causing molecular diffusion and can be estimated as follows (Macintyre et al., 1995),

$F_{\text {atm }}=k\left(C_{\mathrm{w}}-\alpha C_{\text {air }}\right)$

where $C_{\mathrm{w}}$ and $C_{\text {air }}$ are the radon concentrations in water and air $\left[\mathrm{Bq} / \mathrm{m}^{3}\right]$, respectively; $\alpha$ is the partition coefficient of radon between water and air (dimensionless), which is known for a wide range of temperatures (Clever, 1979) and $k$ is the radon transfer velocity $[\mathrm{cm} / \mathrm{h}]$. The latter can be estimated by using an empirical equation valid for lakes, which was introduced by Macintyre et al. (1995). It includes the wind speed $(u ;[\mathrm{m} / \mathrm{s}])$ and the Schmidt Number $(S c$; dimensionless). The Schmidt Number represents the ratio of the kinematic viscosity of water $\left(1.0043 \times 10^{-6} \mathrm{~m}^{2} / \mathrm{s}\right.$ at $20^{\circ} \mathrm{C}$ and $101.325 \mathrm{kPa}$ ) and the radon molecular diffusion coefficient in water $\left(1.16 \times 10^{-9} \mathrm{~m}^{2} / \mathrm{s}\right.$ at $\left.20^{\circ} \mathrm{C}\right)$.

$k_{600}=0.45\left(u_{10}\right)^{1.6}\left(\frac{S c}{600}\right)^{-2 / 3 \text { or }-1 / 2}$

In Eq. (3), $S c^{-2 / 3}$ is used at wind speeds below $3 \mathrm{~m} / \mathrm{s}$, and $S c^{-1 / 2}$ is used at wind speeds above $3 \mathrm{~m} / \mathrm{s}$ (Crusius and Wanninkhof, 2003). The term $u_{10}$ represents the wind speed $10 \mathrm{~m}$ 
above the water surface. Under the assumption of a homogeneous layer of air above the lake surface and a logarithmic wind profile with a drag coefficient of $1.3 \times 10^{-3}$ at $10 \mathrm{~m}$ height, the wind speed recorded in $2 \mathrm{~m}$ height can be converted into $u_{10}$ by applying an equation given by Large and Pond (1981). In order to compare Schmidt Numbers of different gases, $S c$ is generally standardized by dividing the actual value by the Schmidt Number of $\mathrm{CO}_{2}$ at $20^{\circ} \mathrm{C}$, which amounts to 600 . The subscript " 600 " in $k_{600}$ refers to this standardization.

If the radon sink terms $\lambda_{\mathrm{Rn}} I_{\mathrm{Rn}}$ and $F_{\mathrm{atm}}$ do not quantitatively correspond to the radon source terms $F_{\mathrm{diff}}$ and $\lambda_{\mathrm{Rn}} I_{\mathrm{Ra}}$, advective radon transport across the sediment/lake water interface $\left(F_{\text {adv }}\right)$ must be considered as an additional input term in order to satisfy the radon mass balance given in Eq. (1). By dividing the estimated advective radon flux by the radon concentration of the discharging groundwater (groundwater end member), the groundwater discharge rate can be determined.

The diffusive radon flux from the sediment $\left(F_{\text {diff }}\right)$ can be calculated by means of batch experiments, as described by Corbett et al. (1998). However, due to the widespread, diffuse interface between lake water and aquifer, $F_{\text {diff }}$ was not estimated that way. An alternative approach discussed by Cook et al. (2008) was chosen: $F_{\text {diff }}$ was determined by assuming that the lowest excess radon concentration detected in a lake represents the contribution of the radon inventory supported by diffusive radon input only. In areas where advective groundwater inflow could be verified by significantly higher excess radon concentrations, the influence of diffusive radon input was considered insignificant. The applied approach is common in other environments where advective groundwater discharge dominates other radon inputs (Cable et al., 1996; Peterson et al., 2008).

As shown by many authors, defining a groundwater end member can be challenging, as radon is often highly-variable in groundwater (Crusius et al., 2005; Dulaiova et al., 2008). As a result, the groundwater end member often represents the largest uncertainty for estimating radon-derived groundwater discharge. A further complication is that the radon signal of an aquifer can be superimposed by the radon signal of the sediment layer of a lake if the residence time of the discharging groundwater in the sediment exceeds a few days. To determine the groundwater end member, one can rely on measurements from groundwater wells, fluids sampled from seepage meters, or perform sediment equilibration experiments. In areas where diffuse seepage is the main mode of discharge, as is observed for the lakes in this study, equilibrating water with sediment is a better way to estimate the radon concentration of advecting fluids. With flow rates on the order of a few centimeters per day, there should be ample time for the fluids to equilibrate with ${ }^{226} \mathrm{Ra}$ in the solid phases of the lake sediment (Burnett et al., 2007; Santos et al., 2009).
Hence, in the present study the radon end member concentrations were determined by performing sediment equilibration experiments as described by Corbett et al. (1998) assuming that the radon concentration of the discharging groundwater is in radioactive equilibrium with the radium concentration of the sediment material as recommended in the literature (Burnett et al., 2007). However, whenever possible, groundwater samples from boreholes close to the lakes were taken using a peristaltic pump and also analyzed for their radon concentration.

\subsection{Study area}

The study area is located within the Plains region of the Canadian Boreal Forest, in the vicinity of Fort McMurray (Fig. 1). The seasons are characterized by large precipitation and temperature fluctuations. The average monthly temperature ranges from $-18.8^{\circ} \mathrm{C}$ to $16.8^{\circ} \mathrm{C}$ (Environment Canada, 2009). Long term observations at Fort McMurray (19442003) show a mean annual precipitation of $445 \mathrm{~mm}$ and an annual lake evaporation of $575 \mathrm{~mm}$ (Alberta Environment, 2005), resulting in a water deficit in the surface waters bodies, which must be balanced by surface water runoff and/or groundwater discharge into the lakes.

The surficial geology of the region is comprised of glacial drift and fluvial sediments of varying thickness. The region north of Fort McMurray is underlain by ground moraine, outwash sands and gravels with drift thickness between 30 and $60 \mathrm{~m}$. Also, areas of fine grained, silty-clay, lacustrine deposits 10 to $20 \mathrm{~m}$ in depth are noted. The underlying bedrock in the area is the Lower Cretaceous Grand Rapids formation; a fine grained sandstone, with siltstone and silty shale layers, representing a shoreface facies (Bayrock, 1971). South of Fort McMurray in the Stony Mountain uplands, surficial geology is made up of the Kinosis till with isolated aeolian deposits. The thin mantle of till overlays the Upper Cretaceous La Biche formation of shale and silty shale bedrock in major parts the region (Bayrock and Reimchen, 1974).

Two exemplary lakes were studied in detail: Lake NE 7 (hereafter referred to as Lake A) is situated to the NE of Fort McMurray $\left(57.156^{\circ} \mathrm{N} ; 110.86^{\circ} \mathrm{W}\right)$. It is characterized by a surface area of $111900 \mathrm{~m}^{2}$ and a water volume of about $112300 \mathrm{~m}^{3}$. The catchment area covers approximately $5.79 \mathrm{~km}^{2}$. The maximum water depth is about $2 \mathrm{~m}$ and the average water depth is about $1 \mathrm{~m}$ (Bennett et al., 2008; Gibson et al., 2010).

Lake SM 8 (hereafter referred to Lake B) is much larger than Lake A. It is situated in the Stony Mountains south of Fort McMurray $\left(56.21^{\circ} \mathrm{N} ; 111.20^{\circ} \mathrm{W}\right)$ about $105 \mathrm{~km}$ away from Lake A. The lake surface area is about $1912500 \mathrm{~m}^{2}$ and its water volume approximately $1694600 \mathrm{~m}^{3}$. The catchment area covers around $7.72 \mathrm{~km}^{2}$. The maximum water depth of the lake is about $2.5 \mathrm{~m}$; its average water depth is $0.89 \mathrm{~m}$ (Bennett et al., 2008; Gibson et al., 2010). 


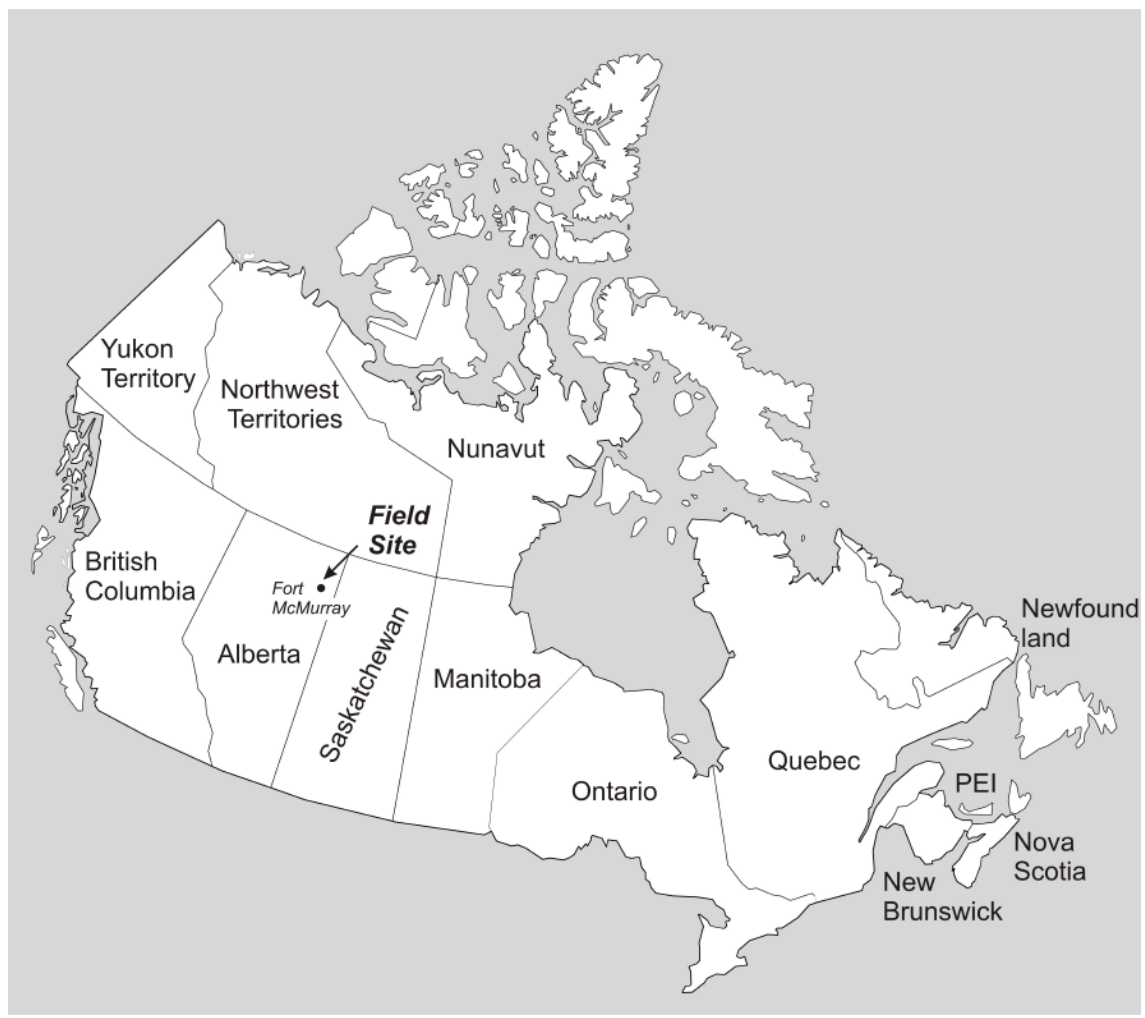

Fig. 1. Map of Canada showing the field site, PEI: Prince Edward Island.

The areas, which directly surround both lakes, consist of riparian peat land with organic material that changes from a floating-marsh with grasses adjacent to the lakes to mosses and extensive peatland cover with a range of sedge, small shrub and forest cover throughout the catchment areas. Both catchment areas display poorly developed drainage patterns, with no evidence of channelized surface water inflow into the lakes via rivers or creeks. Both lake basins are covered by fine-textured silt and organic matter composed of $0.3-0.5 \mathrm{~m}$ of loose and flocculent gyttja. At Lake B, a small area of the lake bed was exposed at the shoreline revealing predominantly sand size sediments without appreciable silt size sediments.

\subsection{Sampling and sample analysis}

Surveys were carried out in March and July 2008. Since the lakes are not connected to any road network, access via helicopter and floatplane was necessary to reach the sites. The March campaign focused on the qualitative identification of radon in the lake waters. In July, detailed investigations were carried out with the aim of a quantitative estimation of the actual groundwater discharge rates. Since the lakes are part of an on-going monitoring program for acid-sensitive lakes in Alberta (RAMP 2004), additional information (e.g. wind speed data) and infrastructure (e.g. boat, groundwater wells) was available.
During the March campaign both lakes were covered with ice thickness ranging from 44 to $75 \mathrm{~cm}$ for Lake A and Lake $\mathrm{B}$, respectively. Radon concentrations as well as $\mathrm{pH}$ and electrical conductivity were measured at one spot in the centre of each lake at a water depth of about $80 \mathrm{~cm}$ by drilling a hole in the ice (Fig. 2).

During the July campaign water parameters and radon concentrations of Lake A were measured at four different spots in a water depth of about $40 \mathrm{~cm}$ (Fig 2a). The radon concentration and basic water parameters of Lake B were determined at nine different locations also in a water depth of about $40 \mathrm{~cm}$ (Fig. 2b).

The portable radon-in-gas monitor RAD-7 (Durridge Company, Inc.) was used for measuring radon in the atmosphere and in water (Burnett and Dulaiova, 2003). For radon extraction from the lake water the RAD-Aqua was used in conjunction with the RAD-7. The RAD-7/RAD-Aqua setup allows radon extraction from a continuously running water pump stream into a closed gas loop which is pumped through the RAD-7 detection chamber. Radon extraction is accomplished by spraying the water into a closed air tight plastic cylinder that is part of the closed gas loop. Due to the large water/air interface produced by the water spray, chemical equilibrium between water and gas phase is reached after about $20 \mathrm{~min}$. For determination of the radon partition coefficient between water and air, the water temperature in the 
a

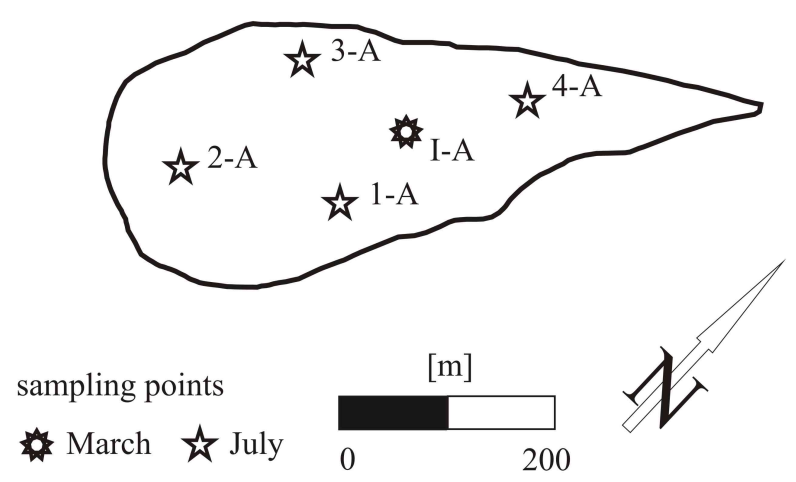

b

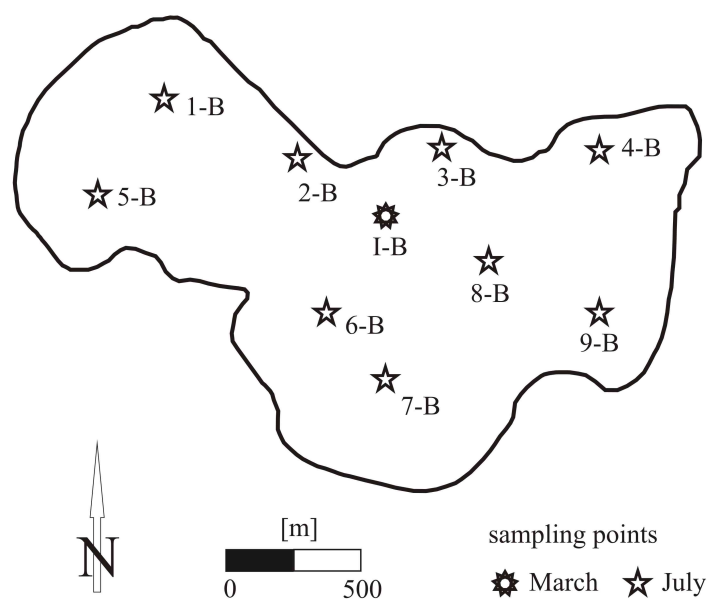

Fig. 2. (a) Lake A and (b) Lake B with sampling points for both campaigns.

system was measured continuously with a HoBo temperature sensor and then calculated using an empirical equation presented by Weigel (1978). For the estimation of the radon concentration in the lake water, the specific counting time of the RAD-7 was set to about $9 \mathrm{~h}$. By considering the system efficiency, the minimum detectable activity (MDA) was estimated to be $2.1 \mathrm{~Bq} / \mathrm{m}^{3}$ (see MDA equations in Currie, 1968). For the determination of radon concentrations in groundwater samples a RAD- $\mathrm{H}_{2} 0$ system was used. That system uses the internal pump of the RAD7 to sparge radon from $250 \mathrm{ml}$ water volume and circulate it to the detection chamber for measurement.

For the estimation of in situ radon production through decay of ${ }^{226} \mathrm{Ra}$ dissolved in the water column, radium was measured using gamma-spectrometry. About $50 \mathrm{~L}$ of lake water was passed through a manganese-impregnated acrylic fiber cartridge, which quantitatively extracts radium from water (Moore and Reid, 1973). In the lab, the fiber was leached with $0.25 \mathrm{~mol} / \mathrm{l}$ hydroxylamine hydrochloride and $\mathrm{HCl}$ to remove the manganese dioxide and the adsorbed radium. The solution was filtered through a $0.45 \mu \mathrm{m}$ membrane filter, and $6 \mathrm{ml}$ of saturated $\mathrm{Ba}\left(\mathrm{NO}_{3}\right)_{2}$ solution was added to the filtrate. $\mathrm{H}_{2} \mathrm{SO}_{4}(17 \%)$ was then added to the solution to precipitate $\mathrm{Ba}(\mathrm{Ra}) \mathrm{SO}_{4}$, which was then collected, rinsed, dried, and stored for several days to allow daughter in-growth (Moore, 1984). The precipitate was then placed on a germanium detector for the quantitative analysis of radium-226. The radionuclide was quantified by measuring the intensity of gamma-rays of ${ }^{214} \mathrm{~Pb}(295.2$ and $351.9 \mathrm{KeV})$ and ${ }^{214} \mathrm{Bi}$ $(609.3 \mathrm{KeV})$. The detection limit of the system for ${ }^{226} \mathrm{Ra}$ is $<0.4 \mathrm{~Bq} / \mathrm{m}^{3}$.

www.hydrol-earth-syst-sci.net/14/79/2010/
Radon equilibrium concentrations of the sediment pore water, i.e. the radon concentrations of the discharging groundwater, were estimated as described by Corbett et al. (1998). In short, batch experiments were set up using $100-220 \mathrm{~g}$ of sediment which equilibrated with water in a stoppered Erlenmeyer flask. After 20 to 25 days (i.e. 5 to 6 radon half-lives) the water in the flask was analyzed using the radon emanation technique (Mathieu et al., 1988; Stringer and Burnett, 2004).

Wind speed needed for the estimation of radon flux from the water body to the atmosphere was measured continuously every $30 \mathrm{~min}$ at $2 \mathrm{~m}$ above the lake by means of an anemometer combined with a Campbell Scientific data logger. This mobile station was installed at each of the sites within the respective lake. The water parameters ( $\mathrm{pH}$, electrical conductivity, temperature) were measured using a YSI Model 600XLM probe.

\section{Results and discussion}

\subsection{Lake A}

Table 1 shows $\mathrm{pH}$, electrical conductivity, and radon concentrations measured in Lake A. The $\mathrm{pH}$ and conductivity are very constant for both campaigns, implying that there is no major seasonal change as well as that the lake water body is well mixed during the July campaign. The radon concentrations detected in the lake water are very low, but still detectable. The concentrations in March were about 50\% higher than the mean July value $\left(0.85 \mathrm{~Bq} / \mathrm{m}^{3}\right)$. This can be explained by the fact that the ice cover on the lake prevented 
Table 1. $\mathrm{pH}$, electrical conductivity, and radon-in-water concentrations at all sampling points (SP) on Lake A for the March (I-A) and the July (1-A to 4-A) campaign. At each spot the same RAD7 setup was used (counting time: $9 \mathrm{~h}$, MDA radon-in-air: $2.1 \mathrm{~Bq} / \mathrm{m}^{3}$ ). Water temperature during the March and July campaign was $2{ }^{\circ} \mathrm{C}$ and $18^{\circ} \mathrm{C}$, respectively.

\begin{tabular}{cccc}
\hline & \multicolumn{3}{c}{ Cond. } \\
SP & $\mathrm{pH}$ & {$[\mu \mathrm{S} / \mathrm{cm}]$} & ${ }^{222} \mathrm{Rn}\left[\mathrm{Bq} / \mathrm{m}^{3}\right]$ \\
\hline I-A & 5.4 & 21 & $1.27 \pm 0.90$ \\
1-A & 5.4 & 21 & $1.10 \pm 0.22$ \\
2-A & 5.4 & 21 & $1.03 \pm 0.18$ \\
3-A & 5.2 & 21 & $0.53 \pm 0.24$ \\
4-A & 5.4 & 22 & $0.75 \pm 0.31$ \\
\hline
\end{tabular}

radon degassing from the water to the atmosphere. During the July campaign, however, radon degassing took place and is considered here.

The radon concentrations measured within the lake during the July campaign ranged between 0.5 and $1.1 \mathrm{~Bq} / \mathrm{m}^{3}$. Considering the uncertainties $(2 \sigma)$, it can be concluded that during that ice free stage radon was distributed almost homogenously within the lake water body. These results confirm assumptions from previous investigations, which suggest that in small well mixed lakes one or two samples are sufficient for obtaining a representative radon concentration for the whole lake water body, allowing reliable estimations of its total radon inventory (Stringer, 2004; Schmidt et al., 2009).

Also the sediment of the lake was found to be distributed homogenously at the five sampling points (Fig. 2a; organicrich silt, with a porosity of 0.8 ). Since the nature of the sediment material did not allow an experimental determination of the diffusive radon flux term $\left(F_{\text {diff }}\right)$, the lowest value of the four radon concentrations detected during the July campaign (3-A, Table 1) was considered to be representative of diffusive radon inputs from the sediment into the lake; i.e. the sum of the radon sink terms $\left(\lambda_{\mathrm{Rn}} I_{\mathrm{Rn}}+F_{\mathrm{atm}}\right)$ valid for sampling point 3-A was assumed to be balanced by $F_{\text {diff }}$ only. Applying the mass balance equation given in Eq. (1) (and neglecting in situ radon production in the lake, since the ${ }^{226} \mathrm{Ra}$ concentration was found to be below the detection limit), the diffusive radon flux at point 3-A was estimated to be $F_{\text {diff }}=0.17 \pm 0.10 \mathrm{~Bq} / \mathrm{m}^{2} / \mathrm{d}$. This value was applied to the whole system.

For the calculation of the radon inventory of the lake water body $\left(I_{\mathrm{Rn}}\right)$ an average water depth of $1 \mathrm{~m}$ was used. For estimation of radon losses due to degassing the wind speed measured during the July campaign was $2.04 \mathrm{~m} / \mathrm{s}$ after converting to $u_{10}$. The radon concentration in the atmosphere was measured very close to the weather station and showed an average value of $0.94 \pm 0.50 \mathrm{~Bq} / \mathrm{m}^{3}$, during the July cam- paign. By applying Eq. (3) the radon transfer velocity $\left(k_{600}\right)$ amounts to $1.07 \mathrm{~cm} / \mathrm{h}$. The resulting atmospheric fluxes are shown in Table 2.

For the estimation of the groundwater end member radon concentration only one monitoring well could be sampled. This shallow well $(1 \mathrm{~m})$ was situated in the riparian peat at the south-western part of the lake, and screened along its entire length with the bottom situated in mineral substrate. Thus, groundwater from that well may represent a mixture of both surface water and groundwater. However, the measured radon concentration $\left(1900 \pm 950 \mathrm{~Bq} / \mathrm{m}^{3}\right)$ was very close to the average radon concentration determined by sediment equilibration experiments $\left(2300 \pm 1120 \mathrm{~Bq} / \mathrm{m}^{3}\right)$. Nonetheless, we considered the higher value as a better estimate for the groundwater end member to be conservative in our discharge estimates.

The sink and source terms for each sampling point of the July campaign and the respective average values are summarized in Table 2. The average value of all four lake water concentrations $\left(0.85 \pm 0.24 \mathrm{~Bq} / \mathrm{m}^{3}\right)$ was used for the estimation of the advective groundwater input into the lake $\left(F_{\text {adv }}\right)$, which amounts to $F_{\text {adv }}=0.14 \pm 0.10 \mathrm{~Bq} / \mathrm{m}^{2} / \mathrm{d}$. By dividing this value by the radon concentration of the discharging groundwater the average groundwater advection rate into the lake was calculated (Table 2). For a lake surface of $111900 \mathrm{~m}^{2}$ the groundwater input into Lake A amounts to $210 \pm 174 \mathrm{~m}^{3} /$ month. After consideration of the lake water volume $\left(112300 \mathrm{~m}^{3}\right)$, this small input rate indicates that groundwater composes a minor component of the overall water budget.

\subsection{Lake B}

Water parameters measured in groundwater wells in the vicinity of Lake B are shown in Table 3. Clearly, $\mathrm{pH}$ and conductivity are generally lower in samples from wells in peat than in wells from sandy areas.

Water parameters as well as radon concentrations measured in Lake B are summarized in Table 4. During the July campaign $\mathrm{pH}$ and conductivity are constant and homogeneously distributed, implying that the lake water is well mixed in relation to those parameters. However, during the March campaign both parameters were higher, especially $\mathrm{pH}$, with a value of 6.3. This value is closer to that of the groundwater measured from the sandy area north of the lake (Table 3), implying that the sampling point is influenced by higher groundwater discharges during the winter.

By comparing the radon data (Table 4) to the concentrations detected in Lake A two things become apparent: (i) the values measured in Lake B are significantly higher and (ii) the concentrations measured in Lake B are not distributed as homogenously as in Lake A. The northern part of Lake $\mathrm{B}$ is characterized by significantly higher radon concentrations $\left(>33 \mathrm{~Bq} / \mathrm{m}^{3}, n=2\right)$ than the rest of the lake $\left(<21 \mathrm{~Bq} / \mathrm{m}^{3}\right.$, $n=7)$. This indicates that the lake water is not well mixed 
Table 2. Sink and source terms and the calculated advective groundwater flow rate for the July survey at Lake A. Note for SP 3-A it was considered that diffusion is the only radon source.

\begin{tabular}{|c|c|c|c|c|c|}
\hline & \multicolumn{2}{|c|}{ sinks } & \multicolumn{2}{|c|}{ sources } & \multirow{2}{*}{$\begin{array}{l}\text { Advective rate } \\
\qquad[\mathrm{cm} / \mathrm{d}]\end{array}$} \\
\hline & $\lambda_{\mathrm{Rn}} I_{\mathrm{Rn}}\left[\mathrm{Bq} / \mathrm{m}^{2} / \mathrm{d}\right]$ & $F_{\text {atm }}\left[\mathrm{Bq} / \mathrm{m}^{2} / \mathrm{d}\right]$ & $F_{\text {diff }}\left[\mathrm{Bq} / \mathrm{m}^{2} / \mathrm{d}\right]$ & $F_{\mathrm{adv}}\left[\mathrm{Bq} / \mathrm{m}^{2} / \mathrm{d}\right]$ & \\
\hline $1-\mathrm{A}$ & $0.20 \pm 0.04$ & $0.22 \pm 0.02$ & $0.17 \pm 0.10$ & $0.25 \pm 0.16$ & $0.01 \pm 0.01$ \\
\hline $2-\mathrm{A}$ & $0.19 \pm 0.03$ & $0.20 \pm 0.01$ & $"$ & $0.22 \pm 0.14$ & $0.01 \pm 0.01$ \\
\hline $3-\mathrm{A}$ & $0.10 \pm 0.04$ & $0.07 \pm 0.03$ & $"$ & 0.00 & 0.00 \\
\hline $4-\mathrm{A}$ & $0.14 \pm 0.06$ & $0.13 \pm 0.04$ & $"$ & $0.10 \pm 0.08$ & $0.01 \pm 0.01$ \\
\hline Average & $0.15 \pm 0.04$ & $0.16 \pm 0.03$ & $"$ & $0.14 \pm 0.10$ & $0.01 \pm 0.01$ \\
\hline
\end{tabular}

Table 3. $\mathrm{pH}$ and electrical conductivity from groundwater wells in the vicinity of Lake B, located in peat and sand areas.

\begin{tabular}{llcc}
\hline \multicolumn{2}{l}{ Groundwater wells } & $\mathrm{pH}$ & Cond. $[\mu \mathrm{S} / \mathrm{cm}]$ \\
\hline Peat & Average & 4.1 & 53 \\
& Range & $3.6-5.1$ & $30-85$ \\
& $n$ & 13 & 13 \\
Sand & Average & 7.0 & 381 \\
& Range & $6.6-7.4$ & $256-495$ \\
& $n$ & 4 & 4 \\
\hline
\end{tabular}

Table 4. pH, electrical conductivity, and radon-in-water concentrations at all sampling points (SP) on Lake B for the March (I-B) and the July (1-B to 9-B) campaign. n.d.=not determined. Water temperature during the March and July campaign was $1.2^{\circ} \mathrm{C}$ and $18^{\circ} \mathrm{C}$, respectively.

\begin{tabular}{cccc}
\hline $\mathrm{SP}$ & $\mathrm{pH}$ & Cond. $[\mu \mathrm{S} / \mathrm{cm}]$ & ${ }^{222} \mathrm{Rn}\left[\mathrm{Bq} / \mathrm{m}^{3}\right]$ \\
\hline I-B & 6.3 & 31 & $72.8 \pm 16.7$ \\
1-B & n.d. & n.d & $13.8 \pm 2.5$ \\
2-B & 5.8 & 16 & $36.6 \pm 9.7$ \\
3-B & n.d. & n.d & $33.2 \pm 6.5$ \\
4-B & 5.5 & 12 & $15.5 \pm 3.8$ \\
5-B & 5.5 & 14 & $11.2 \pm 2.6$ \\
6-B & n.d. & n.d. & $17.7 \pm 2.0$ \\
7-B & 5.4 & 12 & $12.1 \pm 1.4$ \\
8-B & 5.4 & 12 & $12.7 \pm 2.9$ \\
9-B & 5.4 & 12 & $20.9 \pm 2.8$ \\
\hline
\end{tabular}

horizontally with regard to radon (i.e. the timescale for the mixing of the water body is significantly greater than the half-life of radon), which is a reasonable assumption if the large size and the small depth of the lake are considered.

The radon concentration measured during the March campaign was $73 \pm 17 \mathrm{~Bq} / \mathrm{m}^{3}$, i.e. considerably higher than all the values measured in July. The reason for the higher value is the same as discussed for Lake A. The ice cover observed during the March campaign did not allow radon to degas from the water to the atmosphere leading to elevated concentrations. For the July campaign the loss of radon by degassing was calculated to be between 43 and $46 \%$ of the total radon losses (the remaining radon loss is due to decay, cf. Eq. 1), a range which was also observed elsewhere (Dulaiova and Burnett, 2006). However, if a comparable radon loss by degassing is applied to the radon concentration measured in March (sampling point I-B), the remaining radon concentration in the lake water would theoretically be about $37 \pm 7 \mathrm{~Bq} / \mathrm{m}^{3}$, a value which is comparable to the concentrations detected in July at the sampling points $2-\mathrm{B}$ and 3-B, which are located next to I-B in the northern part of the lake (Fig. 3). This suggests little or no seasonal variability in radon inputs into Lake B. This is further supported by the fact that the mineral soil in that region, which represents the main aquifer, is overlain by thick saturated peat that extends deeper than seasonal frost penetration, implying that groundwater discharge is constant over time. However, future investigations are needed for more detailed information about the seasonal variability in groundwater discharge rates.

In the northern part of the lake, where higher radon values were determined, the sandy bottom of the lake is not covered with organic material. However, in the southern part of the lake, where radon concentrations are lower, the sediment is comparable to the material found in Lake A, consisting of silt with a high organic content covered by gyttja. Furthermore the northern shore is characterized by a bluff that rises from the sandy lake sediments to a level of about 3-5 $\mathrm{m}$ above the lake, probably leading to steeper hydraulic gradients than in the southern part of the lake. Because of the different sediment types and associated sediment permeabilities, the radon distribution pattern found in the lake can be attributed to laterally varying groundwater discharge rates. Qualitative conclusions that can be drawn from the radon data are: (i) that groundwater discharge into Lake B is mainly occurring from the north and (ii) that the discharged groundwater mixes relatively slowly laterally with the water in the southern part of the lake, which is only to a minor degree fed by groundwater discharge. 
Table 5. Sink and source terms and calculated advective groundwater flow rates for the July survey at Lake B $(5 \%=$ sand area; $95 \%=$ silt area).

\begin{tabular}{lcccccc}
\hline & \multicolumn{2}{c}{ sinks } & & \multicolumn{2}{c}{ sources } & Advective rate \\
\cline { 2 - 3 } Area & $\lambda_{\mathrm{Rn}} I_{\mathrm{Rn}}\left[\mathrm{Bq} / \mathrm{m}^{2} / \mathrm{d}\right]$ & $F_{\mathrm{atm}}\left[\mathrm{Bq} / \mathrm{m}^{2} / \mathrm{d}\right]$ & & $F_{\mathrm{diff}}\left[\mathrm{Bq} / \mathrm{m}^{2} / \mathrm{d}\right]$ & $F_{\mathrm{adv}}\left[\mathrm{Bq} / \mathrm{m}^{2} / \mathrm{d}\right]$ & {$[\mathrm{cm} / \mathrm{d}]$} \\
\hline sand area & $5.60 \pm 1.22$ & $4.80 \pm 0.99$ & & - & $10.39 \pm 3.13$ & $0.19 \pm 0.08$ \\
silt area & $2.38 \pm 0.56$ & $1.82 \pm 0.38$ & & $3.07 \pm 1.23$ & $1.13 \pm 0.58$ & $0.04 \pm 0.03$ \\
\hline
\end{tabular}

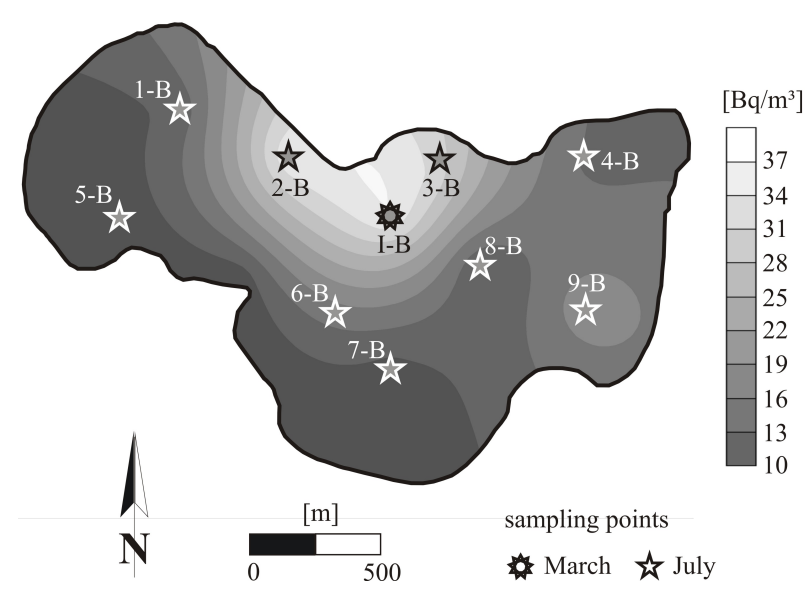

Fig. 3. Radon distribution pattern within Lake B. Sample points I-B, 2-B, 3-B (marked in black) cover the sandy area $(=5 \%)$; 1-B, 4-B-9-B (marked in white) cover the silty area $(=95 \%)$. Note that for I-B a radon-in-water concentration of $37 \mathrm{~Bq} / \mathrm{m}^{3}$ was used, as described in the text.

Based on these observations the lake is divided into two parts for further calculations. Both parts are evaluated separately: an area of high radon concentrations to the north represented by the sampling points I-B, 2-B and 3-B (sandy sediment, with a porosity of 0.37 , covering about $5 \%$ of the lake bottom, which is assumed to be equal to $5 \%$ of lake surface) and an area of low radon concentrations to the south represented by the remaining sampling points (organic-rich silt sediment, with a porosity of 0.77 , covering about $95 \%$ of the lake bottom surface, which is assumed to be equal to $95 \%$ of lake surface). This assumption is based on field observations during summer field work. Sediment samples were collected from several locations allowing us to map the areas of sand and silt material. For the estimation of the diffusive radon flux into the lake, again the lowest value of all radon concentrations detected in the lake was used (5-B, Table 4). The radon sinks at that point $\left(\lambda_{\mathrm{Rn}} I_{\mathrm{Rn}}+F_{\text {atm }}\right)$ were assumed to be balanced by diffusive radon flux only $\left(F_{\text {diff }}\right)$. Thus $F_{\text {diff }}$ was estimated to be $3.07 \pm 1.23 \mathrm{~Bq} / \mathrm{m}^{2} / \mathrm{d}$. For the northern sandy area of the lake it can be assumed that the contribution of radon diffusion to the radon inventory of the lake water is negligible since the region is subject to advective groundwater inputs.
For the calculation of the radon inventory $\left(I_{\mathrm{Rn}}\right)$ of the two parts of the lake, the average water depth $(0.89 \mathrm{~m})$ was used. The wind speed determined during the sampling campaign was converted to $u_{10}$ and amounts to $1.45 \mathrm{~m} / \mathrm{s}$. The radon concentration of the air, recorded onshore very close to the lake, was measured to be $9.33 \pm 3.32 \mathrm{~Bq} / \mathrm{m}^{3}$. By applying Eq. (3) the radon transfer velocity $\left(k_{600}\right)$ amounts to $0.62 \mathrm{~cm} / \mathrm{h}$.

For estimation of the groundwater end member concentrations, two groundwater wells were sampled, one shallow well $(1 \mathrm{~m})$ close to SP 9-B within the riparian peat and one deep well (7 m) close to SP 2-B within the sandy sediments. The shallow well showed a radon concentration of about $2100 \pm 1100 \mathrm{~Bq} / \mathrm{m}^{3}$, the deeper well of $8200 \pm 1270 \mathrm{~Bq} / \mathrm{m}^{3}$. Because of the different well locations together with different substrates, the shallow well represents a potential end member for groundwater discharging into the silty lake area, whereas the deeper monitoring well represents an end member for groundwater seeping into the sandy lake area. Groundwater radon concentrations determined by sediment equilibration experiments were $2690 \pm 1190 \mathrm{~Bq} / \mathrm{m}^{3}$ and $5500 \pm 1610 \mathrm{~Bq} / \mathrm{m}^{3}$ for the southern silty $(n=6)$ and the northern sandy area $(n=3)$, respectively. Thus, radon concentrations determined by using sediment equilibration experiments and measured from groundwater wells are similar. However, as discussed above, the values determined by sediment equilibration experiments are considered to be more reliable. Hence, for further calculations, the values obtained by sediment equilibration experiments were used.

The radon sink and source terms for the two areas are summarized separately in Table 5. Applying the calculated groundwater advection rates and considering the surface areas of the two parts of the lake (sandy area: $0.096 \mathrm{~km}^{2}$; silty area: $1.817 \mathrm{~km}^{2}$ ), the total groundwater discharge into Lake B amounts to $28720 \pm 17980 \mathrm{~m}^{3} /$ month. Related to the different sediment types, it can be concluded, that about $20 \%$ of the total groundwater budget is contributed through the sandy area, the remaining is through the silty area.

\subsection{Relevance to the water budget}

Water yield data as calculated using an isotope mass balance model for Lakes A and B is published by Bennett et al. (2008), based on observations over a three year period 
Table 6. Overall water yield rates into Lake A based on an isotope mass balance model (Gibson et al., 2010) and the related groundwater fraction from 2002 to 2008 .

\begin{tabular}{lccccccc}
\hline & 2002 & 2003 & 2004 & 2005 & 2006 & 2007 & 2008 \\
\hline Total water inflow [m $\left.\mathrm{m}^{3} / \mathrm{a}\right]$ & 963249 & 724939 & 585276 & 941657 & 732135 & 762667 & 995664 \\
Groundwater [\%] & $0.3 \pm 0.2$ & $0.3 \pm 0.3$ & $0.4 \pm 0.4$ & $0.3 \pm 0.2$ & $0.3 \pm 0.3$ & $0.3 \pm 0.3$ & $0.3 \pm 0.2$ \\
\hline
\end{tabular}

Table 7. Overall water yield rates into Lake B based on an isotope mass balance model (Gibson et al., 2010) and the related groundwater portion from 2002 to 2008 .

\begin{tabular}{lccccccc}
\hline & 2002 & 2003 & 2004 & 2005 & 2006 & 2007 & 2008 \\
\hline Total water inflow $\left[\mathrm{m}^{3} / \mathrm{a}\right]$ & 1109399 & 1642001 & 1775981 & 2492359 & 1979535 & 538487 & 2514819 \\
Groundwater [\%] & $31 \pm 19$ & $21 \pm 13$ & $19 \pm 12$ & $14 \pm 9$ & $17 \pm 11$ & $64 \pm 40$ & $14 \pm 9$ \\
\hline
\end{tabular}

(2002-2004). A longer term data set (2002-2008) for the same lakes has been evaluated by Gibson et al. (2010). The water yield rates revised, showing only slight variation from those presented by Bennett et al. (2008).

For Lake A the overall water yield was calculated to be about $995664 \mathrm{~m}^{3}$ for the year 2008 (Table 6). The radon mass balance presented here revealed an input of groundwater which is virtually zero. However, if we apply the calculated advective velocity the groundwater input into the lake amounts to $2520 \pm 2091 \mathrm{~m}^{3} /$ year. Hence, it can be concluded that less than $0.5 \%$ of the overall water inflow is caused by groundwater discharge; the remaining of the total water inflow is surface water runoff. Under the assumption that groundwater discharge into the lake is constant over time, the groundwater fraction of the overall water yield never exceeds 1\% from 2002 to 2008 (Table 6). We emphasize, however, that while groundwater plays an insignificant role in the overall water budget for Lake A, it may still contribute to large amounts of dissolved species. In a coastal lagoon from southern Brazil, for example, groundwater accounted for only about $2 \%$ of total water inputs. However, as the concentrations of dissolved species in groundwater are very high, groundwater-derived fluxes of major ions were equivalent to about $50 \%$ of their total annual inputs (Santos et al., 2008b).

The water yield to Lake B for the year 2008 amounts to $2514819 \mathrm{~m}^{3}$. In the study presented here the annual groundwater discharge into the lake was found to be about $344650 \pm 215700 \mathrm{~m}^{3}$. Therefore, the fraction of groundwater is about $14 \pm 9 \%$ of the overall inflow. However, comparing groundwater discharge to the overall water yield rates from 2002 to 2008 and assuming no interannual variations in groundwater input rates, it is evident that the groundwater fraction of the overall runoff is variable (Table 7). It varies from $14 \%$ in 2005 and 2008 to up to $64 \%$ in 2007 . This implies that, in general, groundwater is an important water source to Lake B.
Three reasons can explain the significant difference in groundwater discharge rates between the two lakes: sediment type, hydraulic gradient, and catchment area. The bottom of Lake A is completely covered by silt and organic material. Silt has a low hydraulic conductivity $\left(k_{\mathrm{f}}\right)$-value and hence a low permeability, which prevents significant groundwater discharge. The bottom of Lake B is also covered with material low in $k_{\mathrm{f}}$; however over approximately $5 \%$ of the lake bottom sandy sediments are exposed. Within that sandy area, higher radon concentrations were detected, which indicates higher groundwater inflow rates within that area. These higher inflow rates are affected by the hydraulic gradients resulting from an increased elevation north of that area, which enhances groundwater discharge rates into the lake. Furthermore the catchment area of Lake A $\left(5.78 \mathrm{~km}^{2}\right)$ is about 52 times larger than its surface area $\left(0.1 \mathrm{~km}^{2}\right)$, the catchment area of Lake B $\left(7.72 \mathrm{~km}^{2}\right)$, on the other hand, is just about 4 times as large as its surface area $\left(1.91 \mathrm{~km}^{2}\right)$. Hence, the significant difference in the catchment area to surface area ratio leads to the higher sensitivity of Lake A towards surface runoff compared to Lake B.

Previous studies of groundwater exchange in Boreal plains ecosystems of Alberta have focused primarily on upland dominated watersheds (Ferone and Devito, 2004; Smerdon et al., 2005). The results presented here are the first reported estimates of groundwater contributions for wetland dominated watersheds which dominate northeastern Alberta in the vicinity of oil sands developments near Fort McMurray. Although both catchment types are situated within the Boreal plains region, their water budget characteristics as well as their chemical (e.g. pH, conductivity, $\mathrm{HCO}_{3}^{-}$) and physical properties (e.g. water residence time, catchment area) are known to be fundamentally different (Prepas et al., 2001).

Upland dominated watersheds are characterized by lower precipitation/evaporation rates, by drier soils and forested hillslopes which results in different surface water flow potential (Devito et al., 2005). These parameters influence the general composition of the lake water budget. Lakes in 
upland dominated watersheds are dominated by groundwater inputs, whereas surface water runoff is of insignificant relevance (Ferone and Devito, 2004; Smerdon et al., 2005).

\section{Summary and conclusions}

The quantification of groundwater discharging into lakes is essential for evaluating the vulnerability of surface waters in relation to changes in local groundwater flow patterns. For this purpose we applied a method incorporating ${ }^{222} \mathrm{Rn}$ as a naturally occurring radioactive noble gas for the evaluation of groundwater discharge rates into two exemplary Boreal lakes in northern Alberta.

We show that using radon to assess groundwater discharge rates via a radon mass balance is a suitable approach. The groundwater discharge fraction of the overall water budget for 2008 ranged from less than $0.5 \%$ for Lake A to about $14 \%$ for Lake B. This indicates that groundwater is more important for Lake B than for Lake A. This finding should be considered if the influence of mining activities on local and regional water and ecosystems is to be evaluated.

Oil sand mining in Alberta significantly alters shallow and deep groundwater resources. Steam-assisted gravity drainage involves injection of steam and pressurization of groundwater formations to extract bitumen, and disposal of brine into deeper formations. One major concern is that abstraction of groundwater will impact surface water bodies and wetlands in the region by altering natural subsurface inputs. Adaptive management strategies therefore require an understanding of the potential for groundwater exchange with surface water bodies. As our radon approach was useful to examine two remote lakes with contrasting groundwater input rates, we recommend that further investigations should cover a broader area to better understand how factors such as sediment types, hydraulic gradients, and catchment areas control groundwater discharge rates. The large number of lakes in the Fort McMurray region makes it ideal for such comparative investigations.

There are some uncertainties associated with the radon mass balance approach. The most prominent of these uncertainties lies in the assignment of the appropriate groundwater end member. Other minor sources of uncertainty for the model involve diffusive inputs from lake sediments and appropriate estimation of the radon flux to the atmosphere. Hence, for an improvement of the radon model these parameters should be subject of future investigations, especially in Boreal environments. Furthermore we neglected surface water as a potential radon source to the surface water body, because riparian peat several metres thick is present in both watersheds and surrounding both lakes, while all surface water moves across this peat. The water, even if it is in contact with shallow groundwater, is not in direct contact with radon producing rocks or sediments. Surface runoff typically cascades from pool to pool down the peat surface during snowmelt and high runoff events and often contains a high proportion of pre-event water. For these reasons we can assume that surface water discharging into the lakes is radon free. In other environments, however, surface water can be a potential radon source.

Our results show, however, that the combination of stable isotopes for the assessment of the overall water budget and radioactive isotopes for the determination of the amount of groundwater provides a unique opportunity for assessing the current status and potential sensitivity of a surface water body to future impacts. In general, the implication for wetland-rich terrain is that increased groundwater discharge rates enhances contact with mineral soils, potentially reducing aquatic ecosystem sensitivity to acid deposition. But increased groundwater contributions may also imply increased sensitivity of lakes and wetlands to groundwater abstraction. Overall, these factors need to be evaluated for a given water body using site-specific information as we have demonstrated.

Acknowledgements. We thank Joel Angen, Tom Carter, and Martin Lacroix for technical and field assistance. Comments on earlier drafts of the manuscript from H. Dulaiova and two anonymous reviewers are appreciated.

Edited by: W. Quinton

\section{References}

Bennett, K. E., Gibson, J. J., and McEachern, P. M.: Water-yield estimates for critical loadings assessment: comparisons of gauging methods versus an isotopic approach, Can. J. Fish. Aquat. Sci., 65, 83-99, 2008.

Bayrock, L. A.: Surficial Geology Bitumont NTS 74E, Research Council of Alberta, Map 34, 1971.

Bayrock, L. A. and Reimchen, T. H. F.: Surficial Geology Waterways NTS 74D, Alberta Research Council, 1974.

Burnett, W. C. and Dulaiova, H.: Estimating the dynamics of groundwater input into the coastal zone via continuous radon222 measurements, J. Environ. Radioact., 69, 21-35, 2003.

Burnett, W. C., Dulaiova, H., Stringer, C., and Peterson, R.: Submarine groundwater discharge: Its measurement and influence on the coastal zone, J. Coast. Res., 1, 35-38, 2006.

Burnett, W. C., Santos, I. R., Weinstein, Y., Swarzenski, P. W., and Herut, B.: Remaining uncertainties in the use of Rn-222 as a quantitative tracer of submarine groundwater discharge, in: A new focus on groundwater-seawater interactions, edited by: Sanford, W., Langevin, C., Polemio, M., and Povinec, P., IAHS Publications, 312, Perugia, Italy, 109-118, 2007.

Burnett, W. C., Peterson, R., Moore, W. S., and de Oliveira, J.: Radon and radium isotopes as tracers of submarine groundwater discharge - Results from the Ubatuba Brazil SGD assessment intercomparison, Estuar. Coast. Shelf Sci., 76, 501-511, 2008.

Cable, J. E., Burnett, W. C., Chanton, J. P., and Weatherly, G. L.: Estimating groundwater discharge into the northeastern Gulf of Mexico using radon-222, Earth Planet. Sci. Lett., 144, 591-604, 1996. 
Clever, H. L.(Ed): Solubility data series, Krypton, Xenon and Radon - gas solubilities, International Union of Pure and Applied Chemistry, Pergamon Press, Oxford/UK, Volume 2, 1979.

Corbett, D. R., Burnett, W. C., Cable, P. H., and Clark, S. B.: A multiple approach to the determination of radon fluxes from sediments, J. Radioanal. Nucl. Chem., 236, 247-252, 1998.

Cook, P. G., Wood, C., White, T., Simmons, C. T., Fass, T., and Brunner, P.: Groundwater inflow to a shallow, poorly-mixed wetland estimated from a mass balance of radon, J. Hydrol., 354, 213-226, 2008.

Crusius, J. and Wanninkhof, R.: Gas transfer velocities measured at low wind speed over a lake, Limnol. Oceanogr., 48, 1010-1017, 2003.

Crusius, J., Koopmans, D., Bratton, J. F., Charette, M. A., Kroeger, K., Henderson, P., Ryckman, L., Halloran, K., and Colman, J. A.: Submarine groundwater discharge to a small estuary estimated from radon and salinity measurements and a box model, Biogeosciences, 2, 141-157, 2005, http://www.biogeosciences.net/2/141/2005/.

Currie, L. A.: Limits for qualitative detection and quantitative determination, Anal. Chem., 40, 586-593, 1968.

Devito, K. J., Creed, I. F., and Fraser, C. J. D.: Controls on runoff from partially harvested aspen-forested headwater catchment, Boreal Plain, Canada, Hydrol. Process., 19, 3-25, 2005

Dulaiova, H. and Burnett, W. C.: Radon loss across the water-air interface (Gulf of Thailand) estimated experimentally from Rn-222-Ra-224, Geophys. Res. Lett., 33, L05606, doi:10.1029/2005GL025023, 2006.

Dulaiova, H., Gonneea, M. E., Henderson, P. B., and Charette, M. A.: Geochemical and physical sources of radon variation in a subterranean estuary - Implications for groundwater radon activities in submarine groundwater discharge studies, Mar. Chem., 110, 120-127, 2008.

Ferone, J. M. and Devito, K. J.: Shallow groundwater-surface water interactions in pond-peatland complexes along a Boreal Plains topographic gradient, J. Hydrol., 292, 75-95, 2004.

Gibson, J. J., Prepas, E. E., and McEachern, P.: Quantitative comparison of lake throughflow, residency, and catchment runoff using stable isotopes: modelling and results from a regional survey of Boreal lakes, J. Hydrol., 262, 128-144, 2002.

Gibson, J. J., Birks, S. J., Kumar, S., McEachern, P. M., and Hazewinkel, R.: Interannual variations in water yield to lakes in northeastern Alberta: Implications for estimating critical loads of acidity, J. Limnol., 69(Suppl. 1), in press, 2010.

Henriksen, A., Kamari, J., Posch, M., and Wilander, A.: Critical Loads Of Acidity - Nordic Surface Waters, Ambio, 21, 356-363, 1992.

Large, W. G. and Pond, S.: Open Ocean Momentum Flux Measurements in Moderate to Strong Winds, J. Phys. Oceanogr., 11, 324-336, 1981.

Macintyre, S., Wanninkhof, R., and Chanton, J. P.: Trace gas exchange across the air-water interface in freshwater and coastal marine environments, in: Methods in Ecology - Biogenic Trace Gases: Measuring Emissions from Soil and Water, edited by: Matson, P. A. and Harriss, R. C., Blackwell Science, Cambridge, USA, 52-97, 1995.

Mathieu, G. G., Biscaye, P. E., Lupton, R. A., and Hammond, D. E.: System for measurement of Rn-222 at low-levels in naturalwaters, Health Phys., 55, 989-992, 1988.
Moore, W. S. and Reid, D.: Extraction of radium from natural water using manganese-impregnated acrylic fiber, J. Geophys. Res., 78, 8880-8886, 1973.

Moore, W. S.: Radium isotopic measurements using germanium detectors, Nucl. Inst. Methods, 223, 407-411, 1984.

Peterson, R. N., Burnett, W. C., Taniguchi, M., Chen, J., Santos, I. R., and Ishitobi, T.: Radon and radium isotope assessment of submarine groundwater discharge in the Yellow River Delta, China, J. Geophys. Res., 113, C09021, doi:10.1029/2008JC004776, 2008.

Prepas, E. E., Planas, D., Gibson, J. J., Vitt, D. H., Prowse, T. D., Dinsmore, W. P., Halsey, L. A., McEachern, P. M., Paquet, S., Scrimgeour, G. J., Tonn, W. M., Paszkowski, C. A., and Wolfstein, K.: Landscape variables influencing nutrients and phytoplankton communities in Boreal Plain lakes of northern Alberta: a comparison of wetland- and upland-dominated catchments, Can. J. Fish. Aquat. Sci., 58, 1286-1299, 2001.

Santos, I. R., Niencheski, F., Burnett, W., Peterson, R., Chanton, J. P., Andrade, C. F. F., Milani, I. B., Schmidt, A., and Knoeller, K.: Tracing anthropogenically driven groundwater discharge into a coastal lagoon from southern Brazil. J. Hydrol., 353, 275-293, 2008a.

Santos, I. R., Machado, M. I., Niencheski, L. F., Burnett, W., Milani, I. B., Andrade, C. F. F., Peterson, R. N., Chanton, J., and Baisch, P.: Major ion chemistry in a freshwater coastal lagoon from southern Brazil (Mangueira Lagoon): Influence of groundwater inputs, Aquat. Geochem., 14, 133-146, 2008 b.

Santos, I. R., Burnett, W. C., Chanton, J., Dimova, N., Mwashote, B., and Peterson, R.: Extended time series measurements of submarine groundwater discharge tracers $\left({ }^{222} \mathrm{Rn}\right.$ and $\left.\mathrm{CH}_{4}\right)$ at a coastal site in Florida, Mar. Chem., 113, 137-147, 2009.

Schmidt, A. and Schubert, M.: Using radon-222 for tracing groundwater discharge into an open-pit lignite mining lake - a case study, Isot. Environ. Health Stud., 43, 387-400, 2007.

Schmidt, A., Stringer, C. E., Haferkorn, U., and Schubert, M.: Quantification of groundwater discharge into lakes using radon222, Environ. Geol., 56, 855-863, 2009.

Smerdon, B. D., Devito, K. J., and Mendoza, C. A.: Interaction of groundwater and shallow lakes on outwash sediments in the sub-humid Boreal Plains of Canada, J. Hydrol., 314, 246-262, 2005.

Stringer, C.: Assessment of groundwater discharge to Lake Barco via radon tracing. Department of Oceanography, Florida State University, Tallahassee, Master Thesis, 58 pp., 2004.

Stringer, C. and Burnett, W. C.: Sample bottle design improvements for radon emanation analysis of natural waters, Health Phys., 87, 642-646, 2004.

Weigel, F.: Radon, Chemiker-Zeitung, 102, 287-299, 1978.

Environment Canada: Canadian Climate Normals or Averages 1971-2000: Fort McMurray A, Alberta, http://climate. weatheroffice.ec.gc.ca/climate_normals/index_e.html, 2009.

Regional Aquatics Monitoring Program (RAMP): 2003 technical report to the Regional Aquatics Monitoring Program, Appendix A8: acid sensitive lakes, 2004.

Western Resource Solutions: Calculation of critical loads of acidity to lakes in the Athabasca Oil Sands Region, Report to the $\mathrm{NO}_{\mathrm{x}}$ $\mathrm{SO}_{\mathrm{x}}$ Management Working Group, Cumulative Environmental Management Association, Fort McMurray, Alberta, 2004. 